doi: 10.26529/cepsj.902

\title{
Editorial
}

\section{Chemistry Education in the Countries of the Former Yugoslavia}

Why is a woman and chemistry education researcher from Germany interested in the development and the situation of chemistry education in the seven new countries of the former Yugoslavia?

Well, Yugoslavia was the country where I grew up. When I think about my childhood and the name Yugoslavia, I have memories of a place where different people lived together in an attractive geographic region where it was possible - in such a small region - to go skiing during the winter, but also spend the whole warm summer at the beach. For me, the country was characterised by a diversity of languages, ethnicities, cultures and religions. These were similar in many ways, but some differences were also noticeable. For me, it made us a "little Germany", where everybody lives together. Germany is the country where I live now.

I went to school in the former Yugoslavia for nine years, starting in 1984, and experienced how chemistry was taught and learned. The differences between my chemistry lessons in German classes and those in the former Yugoslavia were enormous. I cannot say what was better or what was not, but I can say that it was different.

Yugoslavia was made up of six constituent socialist republics: SR Bosnia and Herzegovina, SR Croatia, SR Macedonia, SR Montenegro, SR Serbia and SR Slovenia. In addition, two Socialist Autonomous Provinces, Vojvodina and Kosovo, were members of the federation. The country existed in Southeast and Central Europe for the majority of the twentieth century. Yugoslavia was established after the First World War in 1918 and broke up in the early 199os.

After the end of the Socialist Federal Republic of Yugoslavia, in summer 1991, Slovenia and Croatia declared independence and were recognised by most European countries in January 1992. In April of the same year, Bosnia and Herzegovina's independence was also recognised. In autumn 1991, the Republic of Macedonia declared independence and, in April 1992, the Federal Republic of Yugoslavia was formed, which was a union of Serbia, Montenegro, Vojvodina and Kosovo. In the following years, Kosovo and Montenegro became independent states. The former SR Serbia and the province of Vojvodina are now the Republic of Serbia.

Thus, from a starting point of one country with the same system in all of the republics and both provinces, seven different new countries now exist.

As a chemistry education researcher interested in the development of 
chemistry education, but also as somebody who knew only the one system and one way of chemistry education shared by seven countries, I have a strong interest in and curiosity about the possibilities for the development of chemistry education when starting from one system. Since the fall of socialist politics in those countries, some changes can be seen. I never experienced those changes myself, which is why I am so interested in them. I wanted to see whether the countries are focusing on similar issues or have different foci. Since my roots are in one of these new countries, I have always observed and been interested in the development of chemistry education in the countries of the former Yugoslavia.

The submissions in this focus issue are different in nature, but present a bright picture of good research and development in the countries of the former Yugoslavia.

The paper entitled Chemical Education Research in Slovenia after 1991: A Systematic Review by Iztok Devetak and Vesna Ferk Savec from the University of Ljubljana gives a systematic review of chemistry education research in Slovenia after 1991. Two main research groups exist, in Ljubljana and Maribor, and four main research fields are identified: submicrorepresentations, models and animations; chemistry teacher education; experimental work; and conceptions of basic chemical concepts. This shows a wide range of research.

Croatia is represented in this issue by two papers, both focusing on the research on preservice chemistry teachers. The paper entitled Initial Beliefs of Preservice Chemistry Teachers in Croatia by Lana Šojat examines the beliefs about teaching and learning that preservice chemistry teachers possess prior to commencing their chemistry education courses. The study shows that the beliefs are traditional in nature and, in some cases, are in line with the old Yugoslavian system. The second paper, Evidence of the Development of Pedagogical Content Knowledge Related to Chemical Bonding during a Course for Preservice Chemistry Teachers by Roko Vladušić, Robert Bucat and Mia Ožić, addresses the development of preservice chemistry teachers' pedagogical content knowledge (PCK) related to chemical bonding. A university course on the topic was changed and evaluated. The findings show evidence of the growth of an individual preservice teacher's PCK about chemical bonding. The particular characteristics of the change described by the authors indicate that their source is almost certainly the revised Chemistry Education 2 curriculum.

The paper entitled Chemistry Education in Bosnia and Herzegovina by Meliha Zejnilagić-Hajrić and Ines Nuić from the University of Sarajevo in Bosnia and Herzegovina presents the development of chemistry education in this country. Bosnia and Herzegovina is different to the other countries presented in this special issue, as it is characterised by linguistic, religious and cultural 
diversity. The authors present the education system in their country, as well as the education system for future chemistry teachers.

Mirjana D. Segedinac, Dušica D. Rodić, Tamara N. Rončević, Saša Horvat and Jasna Adamov from the University of Novi Sad present the development of research in the field of chemistry education at their university since the breakup of the Socialist Federal Republic of Yugoslavia. Novi Sad is a city in Vojvodina, which is part of Serbia. The authors take us on a tour of chemistry education research, starting with the integration of the computer in chemistry teaching and learning in the 1990s, through the possibility of including ecochemical content in chemistry curricula, to an investigation of the effectiveness of instructional strategies based on a systemic approach and a triplet model of content representation, using combined measures of students' performance and mental effort.

Fatlume Berisha is the author of the paper Chemistry Education in Kosovo: Issues, Challenges and Time for Action. The contribution from Kosovo is a study based on a multidimensional analysis of the issues and challenges of chemistry education in this country. The author describes the curricula for preuniversity education, with a focus on the challenging field of natural science. She presents conclusions regarding action based on the results.

The paper entitled Challenges and Recommendations for Improving Chemistry Education and Teaching in the Republic of North Macedonia, written by Marina Stojanovska, Ivanka Mijić and Vladimir M. Petruševski from North Macedonia, discusses challenges and recommendations for improving chemistry education and teaching on the primary, secondary and tertiary level in the authors' country. One of the greatest challenges identified is the lack of investment in education and the absence of notable improvements in the conditions for teaching chemistry. The authors give recommendations at different levels, from the need for appropriately educated, qualified and motivated teaching staff, well-equipped laboratories and teaching resources, through the Continuous Professional Development (CPD) of chemistry teachers and the mutual cooperation of all stakeholders in the educational process, to continuous support from the authorities and policy-makers for gifted pupils and chemistry teachers.

This focus issue is completed with two VARIA papers from the wider field of education.

The paper entitled Business School Teachers' Experiences with a Student with Autism Spectrum Disorder by Jaka Vadnjal and Darinka Radoja focuses on business school teachers' experiences with a student with autism, presenting a study that is qualitative in nature. The findings indicate that teachers generally 
express that working with students with autism is a very positive experience, but they describe such teaching as a challenge. The authors point out that cooperation with experts and parents is crucial for success.

The second paper, Advancing the Scholarship of Teaching and Learning using Learning Theories and Reflectivity by Lester Brian Shawa from South Africa, discusses advancing the scholarship of teaching and learning (SoTL) using learning theories and reflectivity. In the article, the author describes the use of a postgraduate diploma module entitled Higher Education Context and Policy to show how a facilitator can draw from learning theories and reflectivity to teach and advance SoTL.

Although the countries of the former Yugoslavia are facing similar changes and challenges, it is good to see their potential and the work that has been put into chemistry education research and development in the last thirty years. I am happy that I had a chance to meet and collaborate with colleagues from almost all of the states. I am very thankful to them for giving me and other readers an insight into the development of their work. Finally, I would like to thank all of the authors for their contributions to this focus issue.

SilviJa Markic 